\title{
Aktivitas RolePlay (RP) Thailand Idol dan Pengaruhnya terhadap Pembentukan Kehidupan Baru di Dunia Maya
}

\author{
Florentia Christina Monica, Ahmad Junaidi \\ florentiachristina20@gmail.com,ahmadd@fikom.untar.ac.id \\ Fakultas Ilmu Komunikasi Universitas Tarumanagara
}

\begin{abstract}
The development of times from time to time was so increasing. Communication technology is one of them who got increased rapidly. This development of communication technology was also certainly in line with the development of human intelligence who got more creative and innovative this day. Social media is a form of media development, that we know them as a "new media". For example, a feature from Line Chat App called Line Open Chat (OC) from fans club category. There's a phenomenon this day that comes from this fan culture in OC, named "roleplay" (RP). RP is a role game in a social media using other's people characters (usually using an idol's character). This research was looking for how is the life and the activities of members in cyberspace and their impact to a formation of a new world. The players usually adapt their activities and life from real life, but in the RP's world, their entire activities is the life that humans imagine and create for themselves. This phenomenon will form into a virtual community or a network society in a cyberspace, then with times goes by time this phenomenon will referring to a concept of social simulation and create a formation of a new world. This research uses a qualitative case study method with observation, interview, and documentation study.
\end{abstract}

Keywords: cyberspace, network society, new media, new world, roleplay, social simulation

\begin{abstract}
Abstrak
Seiring berkembangnya zaman, interaksi komunikasi antar manusia pun kian mengalami perkembangan. Salah satu contoh perkembangan yang dapat dilihat adalah media komunikasi. Salah satu bentuk perkembangan media tersebut adalah media online atau media digital. Melalui media online atau digital dikenal istilah baru dalam perjalanan perkembangan media, yaitu "new media" atau "media baru". Salah satu media online tersebut dalam penelitian ini adalah sebuah fitur yang ada pada media online chatting line yaitu "open chat" pada kategori fans club. Salah satu fenomena baru dari kelompok penggemar dalam media online ini adalah fenomena roleplay. Roleplay merupakan sebuah permainan peran di media sosial dengan menggunakan karakter orang lain yang biasanya adalah sosok yang diidolakan. Penelitian ini akan melihat bagaimana kehidupan adan aktifitas para pemain roleplay dalam dunia maya serta dampaknya pada pembentukan dunia baru. Dalam roleplay biasanya mereka akan melakukan aktifitas dan kegiatannya di media sosial satu sama lain seperti biasa layaknya kehidupan di dunia nyata, hanya saja kehidupan ini adalah kehidupan yang dikehendaki dan dibuat sendiri oleh manusia, khususnya dirinya sendiri sebagai pemain. Fenomena ini kemudian akan membentuk sebuah komunitas virtual dan/atau network society dalam cyberspace. Kemudian network society dalam cyberspace ini akan membuat sebuah simulasi sosial yang kemudian akan mengacu pada pembentukan dunia baru. Penelitian ini menggunakan metode kualitatif studi kasus dengan teknik pengumpulan data melalui observasi, wawancara, dan studi dokumentasi.
\end{abstract}

Kata Kunci: dunia baru, masyarakat jejaring, media baru, roleplay, ruang siber, simulasi sosial 
Florentia Christina Monica, Ahmad Junaidi: Aktivitas Roleplay (RP) Thailand Idol dan Pengaruhnya terhadap Pembentukan Kehidupan Baru di Dunia Maya

\section{Pendahuluan}

Manusia adalah makhluk sosial yang tidak luput dari kehidupan sosial, seperti berinteraksi satu sama lain. Secara umum, interaksi berarti berhubungan dan/atau hal-hal yang berkaitan dengan saling melakukan aksi komunikasi dan (KBBI, 2016). Salah satu bentuk interaksi sosial adalah komunikasi. Harold D. Lasswell mendefinisikan komunikasi sebagai, who says what, in which channel, to whom, with what effect? (siapa mengatakan apa, melalui media apa, kepada siapa, dengan apa dampaknya?). Seiring berkembangnya zaman, banyak hal yang juga ikut berkambang. Teknologi semakin maju, mengikuti dan diikuti juga dengan kecerdasan manusia yang terus berkembang. perkembangan teknologi ada karena manusia kini juga semakin kreatif, dan inovatif. Salah satunya adalah perkembangan teknologi di bidang komunukasi atau media komunikasi, seperti yang kita ketahui saat ini sebagai "new media" atau media baru.

Perkembangan media komunikasi sendiri dijelaskan oleh Rulli Nasrullah (2017:69) dalam bukunya, "Media Sosial Perspektif Komunikasi, Budaya, dan Sosioteknologi" dengan konsep mediamorfosis yang dipopulerkan oleh Roger Fidller (2003). Mediamorfosis hadir akibat hubungan yang terjadi antar manusia dengan teknologi. Hal ini terjadi karena adanya inovasi-inovasi sosiologis dan teknologi yang membuat struktur baru bagi kehidupan manusia. Berkembangnya cara berkomunikasi, berinteraksi, dan bersosialisasi antar manusia merupakan bukti dari adanya mediamorfosis ini.

Ada 3 konsep mediamorfosis. Pertama, Koevoluasi. Koevoluasi ini berkaitan dengan kode, simbol, atau bahasa. Dalam perkembangan media digital kode atau symbol telah menjadi bahasa baru dalam komunikasi. Seperti contoh, emotion yang kerap digunakan dalam berkomunikasi di media sosial. Kedua, konvergensi. Konsep konvergensi ini mengarah pada realitas akan adanya evolusi yang terjadi di media. Teknologi komunikasi atau media baru yang muncul merupakan sebuah hasil konvergensi dari media sebelumnya. Ketiga, kompleksitas. Konsep ini ada berdasarkan perubahan-perubahan yang berdasarkan prinsip kekacauan (chaos) yang terjadi di masyarakat. Hal inilah yang melahirkan gagasan baru yang mentransformasikan sistem kehidupan manusia.

Menurut Rulli (2017:1), kemajuan teknologi komunikasi serta kecanggihan perangkatnya ini seakan menghadirkan "dunia dalam genggaman". Istilah ini selaras dengan yang diutarakan oleh Thomas L. Friedman (2007) yaitu "the world is flat" atau dunia yang rata di mana semua orang dapat mengakses apapun dari manapun. Istilah lain juga selaras dengan yang diutarakan oleh Richard Hunter (2002) yaitu "world without secrets" bahwa kehadiran new media atau media baru ini membuat informasi menjadi terbuka dan mudah dicari. Leski Rizkinaswara mencatat dari hasil survey Asosiasi Penyelenggara Jasa Internet Indonesia (APJII), pengguna internet di Indonesia mencapai 150 juta jiwa dengan 142.8 juta jiwanya pengguna internet mobile, pulau Jawa memiliki jumlah pengguna internet terbanyak yaitu 95.3 juta jiwa.

Line adalah salah satu bentuk dari teknologi komunikasi berbasis internet saat ini. Line sendiri memiliki beragam fitur, salah satunya adalah Line Open Chat atau yang biasa disingkat menjadi OC. Line Open Chat adalah sebuah fitur obrolan grup yang dibuat agar para pengguna dapat bergabung dan berinteraksi dengan pengguna lainnya yang memiliki ketertarikan yang sama secara anonim. OC sendiri menyediakan beragam kategori grup obrolan yang dapat dipilih oleh penggunanya, 
salah satunya adalah kategori fans clubs. Inilah kelebihan dari media baru yang menjadi sebuah media yang paling memungkinkan manusia dapat memilih dan menentukan sendiri medianya sesuai kebutuhannya secara semakin rinci dan jelas, seperti pada teori uses and gratification.

Kemudian ada sebuah fenomena baru yang datangnya dari kelompokkelompok penggemar ini, khususnya yang akan dibahas adalah kelompok penggemar dalam OC. Para penggemar ini membuat sebuah permainan peran di media sosial, yang biasa peran yang dimainkan adalah peran idola-idolanya, permainan ini disebut dengan "roleplay" atau RP. Nisya Ghaissani (2017:24) dalam penelitiannya menjelaskan roleplay sebagai, "Roleplay is a fan activity where someone pretends to be a character that they idolized in sum, they play arole. In fandom world, celebrity roleplaying not only can be done in theatrical stage act (live performance), but also be done in the world of cyber, that is through social networking website's account." (Ardiani, 2013)

Dalam teori dramaturgi oleh Ervin Goffman juga membagi dua identitas diri front stage, diri yang ditunjukkannya di depan khalayak, dan back stage, dirinya yang sebenarnya dari seseorang. Seperti layaknya pertunjukan teater yang diperlukan kesiapan atau perlengkapan pertunjukannya yang disebut Goffman sebagai "impression management" (Shiefti, 2016:46).

Pengguna-pengguna atau para pemain RP di OC ini kemudian berkumpul menjadi sebuah grup atau komunitas baru dalam dunia virtual. Sekelompok orang ini kemudian akan membentuk komunitas virtual atau bahkan sebagai network society di dalam cyberspace.

Seorang ahli filosofi dari Oxford, Nick Bostrom sempat merilis sebuah literasi pada tahun 2003 berjudul "Are We Living In A Computer Simulation?" yang baru-baru ini hipotesa dalam tulisannya tersebut menjadi sangat ramai diperbincangkan di internet. Hipotesanya disebut sebagai "simulation hypothesis". Singkatnya, hipotesa ini menyatakan bahwa dengan kemajuan teknologi di dunia saat ini dapat memungkinkan manusia di masa depan atau mungkin saat ini dapat menciptakan sebuah simulasi dari dunia yang telah ada (Nick, 2003:243). Dengan kata lain, manusia dapat menciptakan seperti sebuah dunia baru.

Konsep simulasi ini juga sempat dibahas oleh Jean Baudrillard (1994) sebagai "simulations and simulacra". Teori ini menjelaskan bagaimana kesadaran "real" di benak khalayak semakin berkurang digantikan dengan realitas semu yang disebabkan oleh imaji yang disajikan media atau yang terbentuk di penggunanya yang terus menerus dikonsumsi. ada 4 tahap proses dalam term simulacra ini menurut Bell (2001), yaitu tanda (sign) merupakan presentasi dari realitas; kemudian tanda mendistorsi realitas; selanjutnya realitas menjadi semakin kabur; dan yang teakhir tanda tidak lagi menjadi realitas melainkan imaji telah menggantikannya.

Penelitian ini akan melihat salah satu bentuk dari dunia simulasi dari fenomena RP ini. Tujuan dan rumusan masalah yang diangkat adalah untuk mengetahui bagaimanakah aktifitas-aktifitas dan kehidupan yang dilakukan di dunia RP sehari-harinya yang berakhir pada terciptanya dunia dan kehidupan baru bagi manusia di dunia maya. Manfaat penelitian ini diharapkan dapat memberi pemahaman akan begitu besarnya dampak media baru yaitu media digital atau media online ini bagi manusia dan sebagai bukti contoh nyata dari pemahaman mengenai media baru dan dunia maya, serta diharapkan masyarakat khususnya pembaca dapat peka terhadap dampak yang dihasilkan dari penggunaan media online. 


\section{Metode Penelitian}

Pendekatan penelitian ini adalah kualitatif studi kasus. Bogdan dan Taylor (1975) mendefinisikan penelitian kualitatif sebagai prosedur penelitian dengan hasil data yang deskriptif berupa kata-kata tertulis atau lisan dari orang dan perilaku yang diamati dan diteliti (Lexy, 2017). Peneliti menggunakan pendekatan ini untuk menjawab pertanyaan-pertanyaan penelitian yang sebelumnya telah disebutkan. Dalam hal ini, peneliti akan mengeksplorasi fenomena dalam kehidupan manusia secara khusus dalam dunia RP pada komunitas atau grup RP pada OC "RPRLBL_HEH_(SERIES)". Grup ini adalah grup RP secara khusus untuk Thailand Idol dan telah memiliki sekiranya 620 anggota ketika penulis memulai penulisan ini, yaitu sekitar bulan November 2020. Grup RP ini telah berdiri sejak 16 Juni 2020 dan masih aktif hingga saat ini.

Metode pengumpulan data yang digunakan adalah dengan 3 cara, yaitu observasi, wawancara, serta studi dokumentasi. Observasi dilakukan dengan cara penulis ikut bergabung kedalam grup tersebut dan ikut mengambil peran dan bermain RP bersama dengan grup tersebut. Sebelumnya peneliti telah bergabung kedalam grup ini sejak 15 Juli 2020. Peran peneliti disini biasa dikenal dengan "Om Thanat". Metode wawancara juga digunakan oleh peneliti dengan empat informan yaitu, Patrick/Pet sebagai anggota aktif yang perannya sebagai orang terdekat dari penulis, Ohm Pawat sebagai anggota aktif lainnya, Ibu Negara Gun sebagai admin utama dari grup ini, serta Puim sebagai mantan anggota grup. Metode terakhir adalah dengan studi dokumentasi. Metode ini dilakukan peneliti dengan mengumpulkan hasil-hasil dokumentasi seperti foto-foto dari aktifitas dan kegiatan di dalam grup.

Teknik pengolahan dan analisis data dilakukan pada saat dan setelah penelitian berlangsung.hasil temuan observasi seperti foto dan cerita serta pengalaman langsung yang diterima peneliti selama waktu penelitian dikumpulkan dan dicatat dalam penelitian sampai data yang diterima dirasa cukup. Wawancara juga dilakukan selama penelitian berlangsung dengan metode wawancara tidak terstruktur. Wawancara dilakukan secara virtual personal chat dengan keempat informan.

Teknik keabsahan dan validitas data penelitian penulis menggunakan metode triangulasi. Peneliti pertama melakukan observasi secara terus-menerus, kemudian peneliti melakukan wawancara sambil memastikan kembali apakah data hasil wawancara yang ditemukan peneliti dalam penelitian ini sama dengan yang ditemukan dilapangan ketika observasi dilaksanakan, kemudian pengumpulan dokumentasi berupa foto-foto editan dan screenshot obrolan grup juga akan mendukung validitas data temuan. Selain itu peneliti juga melakukan wawancara dengan mantan anggota yang belum lama meninggalkan grup untuk mendukung lagi kebenaran dari temuan data penelitian.

\section{Hasil Temuan dan Diskusi}

Setiap pengguna yang akan bergabung ke dalam grup RP ini bisa memilih sendiri karakter yang ingin ia mainkan dengan membuat nama dan foto profilnya sesuai dengan profil karakter yang dimainkannya. Kemudian ia akan langsung tergabung dalam grup obrolan tersebut. Keseharian dari para pemain atau anggota grup ini akan membuat dirinya seakan adalah seorang yang ia mainkan. Baik 
individunya sampai dunianya adalah hak para pemain serta juga diatur oleh admin yang menjadi pengontrol berjalannya grup.

Grup roleplay RPRLBL_HEH(SERIES) ini pada tanggal 16 Juni 2020. Hingga saat penulisan ini, usia grup RP ini hampir mencapai 6 bulan. Grup ini mulanya dibuat oleh Ibu Negara Gun sebagai admin utama dipertengahan pandemi Covid-19. Saat itu, orang-orang termasuk informan ini sendiri mulai merasa bosan dan melakukan berbagai pencarian kegiatan baru. Saat itulah ia mulai membuat grup ini dan tanpa diduga, perkembangan grup ini meningkat pesat dalam hitungan anggota dan kegiatan didalamnya.

Saat itu, informan sebagai pemilik grup ini membagikan link grup ini ke grup-grup OC lain dan membuka kesempatan untuk 10 orang pertama menjadi coadmin, dan akhirnya terbentuklah admin-admin yang ada saat ini. Para admin juga anggota (member) di grup RP ini memiliki loyalitas yang cukup tinggi. Seringkali admin dan member mengadakan kuis-kuis atau tantangan berhadiah sehingga hal ini menjadi salah satu daya tarik dari grup ini dimata khalayak, khususnya calon-calon anggota.

Sama seperti masyarakat dunia nyata, dalam masyarakat berjejaring atau komunitas virtual dalam RP ini juga memiliki aturan-aturan yang disusun oleh para admin untuk mengontrol jalannya grup. Para admin disini juga sama fungsinya seperti pengurus komunitas. Informan Gun sendiri menyebutkan fungsi-fungsi admin ini baginya sebagai: 1) bisa menggantikan ibu negara Gun jika sedang tidak on di obrolan; 2) bisa diajak kerjasama dalam mengurus grup open chat ini; 3) bisa meramaikan grup jika sedang sepi.

Gambar 1. Peraturan Grup RPRLBL_HEH_(SERIES)

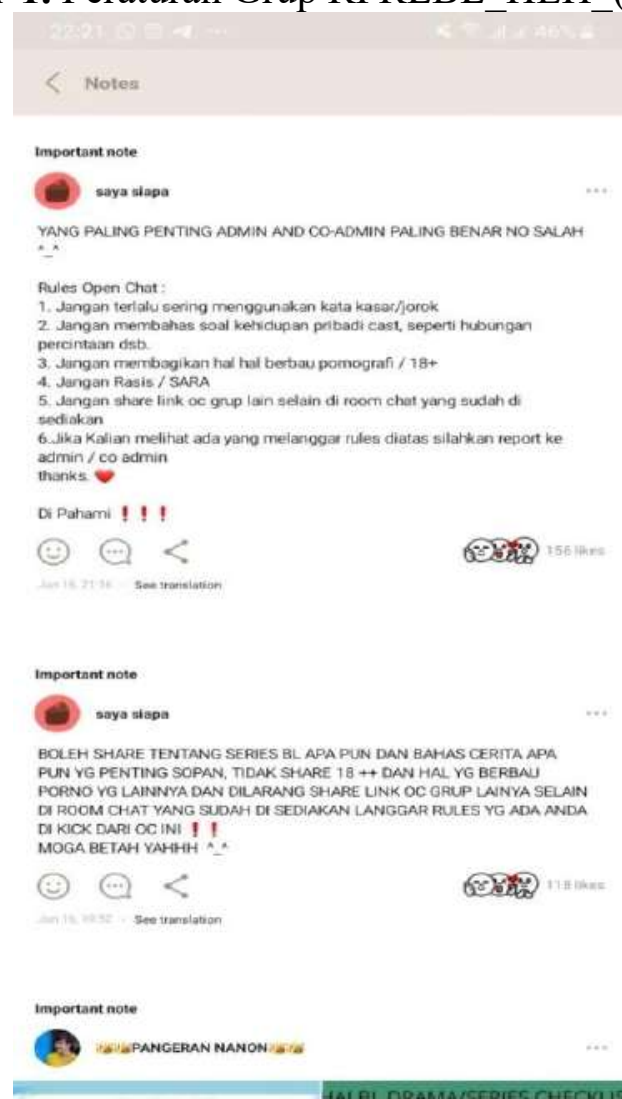

Sumber: Dokumentasi Peneliti 
Grup ini telah 3 kali melakukan perubahan. Nama pertamanya adalah "GMMTV", kemudian kedua berganti menjadi "raikantopeni", hingga nama inilah nama terakhir yang masih digunakan saat ini. Nama "RPRLBL_HEH_(SERIES)" ini berasal dari 5 kata: 1) RP berasal dari kata roleplay, dimana memang grup open chat ini membahas dan melakukan kegiatan RP; 2) RL berasal dari kata real life karena awal grup ini berjalan dengan RL bukan RP; 3) BL berasal dari kata boys love; 4) HEH berasal dari kebiasaan para member yang jika marah menggunakan kata "heh"; 5) SERIES dimana kebanyakan dari hype dunia per-Thailand-an saat ini berasal dari drama series.

Dalam dunia Roleplay, aktivitas dan kegiatan yang dilakukan oleh setiap anggota beragam. Aktivitas dan kegiatannya tidak berbeda jauh dengan apa yang biasa dilakukan manusia di dunia nyata, hanya saja hal-hal itu dilakukan di media virtual dengan manusia-manusia juga di dunia virtual. Melalui hasil observasi, penulis melihat grup ini terbilang sangat aktif, kegiatannya beragam hampir setiap hari.

Informan Pet menjelaskan pengertian RP adalah sebuah dunia khayal dimana seseorang dapat memainkan peran menjadi orang lain dengan sikap atau perilaku sesuai keinginannya sendiri. Kemudian dia juga menjelaskan dunia RP adalah dunia khayalan, dunia palsu, dunia buatan manusia, secara khusus para pemain-pemainnya, dimana setiap orang tidak menunjukkan wujud aslinya, melainkan memainkan peran sebagai orang lain. Informan Pawat juga mengatakan dunia RP seperti memiliki dunia baru dimana seseorang bisa mengaplikasikan sendiri apa saja yang diinginkannya, seperti imajinasi seseorang dapat terealisasikan. Informan Puim menjelaskan RP dimana seseorang memerankan karakter idolanya dengan karakter yang sebisa mungkin mirip dengan orangnya tersebut, dan dunia RP adalah tempat orang tersebut memainkan perannya.

Kehidupan dalam dunia RP adalah bebas, bervariasi, dan instan. Bebas berarti, mau melakukan apapun bisa, misalnya hal-hal yang tidak bisa dilakukan di dunia nyata, seseorang bisa seperti merasa melakukannya di dunia RP-nya. Bervariasi berarti, melakukan kegiatan apa saja bisa dengan beragam bahkan lebih beragam dari kegiatan di dunia nyata. Karena sifatnya dunia RP adalah dunia imaji dari manusia maka manusia dapat membuat apa saja dan melakukan apa yang ada dalam imajinasinya sekreatif dan seunik apapun (bahkan yang tidak masuk akal). Instan berarti segalanya yang ada yang diinginkan di RP sudah tersedia. Seperti kata informan Pawat, "tinggal lakukan dan edit sesuai keinginan".

Informan Pawat juga sempat menyebutkan sistem-sistem utama dalam bermain RP. Pertama, pemain perlu memilih dan menentukan dulu face claim-nya, kemudian setelahnya baru bisa mendalami peran yang dimainkannya. Di RP juga memiliki 2 tipe permainan peran:

OOC (Out Of Character) adalah dimana pemain memainkan peran dengan karakter atau sifat yang agak berbeda dan tidak terlalu sama dengan kehidupan dan karakter asli aktor/artis yang diperankannya

Non-OOC (Non Out Of Character) adalah kebalikan dari OOC, dimana hampir sebagian atau semuanya sesuai dengan karakter dan kehidupan nyata dari aktor/artis yang dimainkan perannya.

Kehidupan di dunia RP ini tidaklah jauh berbeda, hanya saja tidak terlalu detail seperti dunia nyata. Karakter dan perannya juga bisa sangat beragam, bisa juga ada kesamaan peran dalam satu grup. Hal tersebut tidak terlalu berarti bagi para pemain karena setiap pemain dapat membuat dan memainkan ceritanya masing- 
masing. Dalam RP juga ada gen-gen dan keturunan serta keluarga besar yang dibuat oleh setiap pemainnya. Begitu juga dengan profesi, setiap karakter biasa memiliki profesi sendiri atau mungkin dibuat terkadang bisa memainkan peran-peran profesi. Setiap kegiatan atau acara atau aktivitas yang dilakukan sehari-hari oleh setiap anggota biasanya menggunakan kata-kata atau gambar atau suara juga video untuk membuat gambaran kehidupan atau kegiatan atau aktivitas itu terasa nyata.

Ada beberapa aktivitas kegiatan yang biasa dilakukan oleh anggota member. Beberapa kegiatan ini juga ada yang pernah peneliti ikuti alurnya dalam obrolan chat. Kegiatan-kegiatan tersebut antara lain:

- Pernikahan dan perceraian

- Khitanan

- Kelahiran anak

- Liburan atau open trip

- Perayaan ulang tahun

- Clubbing

Gambar 2. Gambar Kegiatan-kegiatan RP yang Sudah Disunting

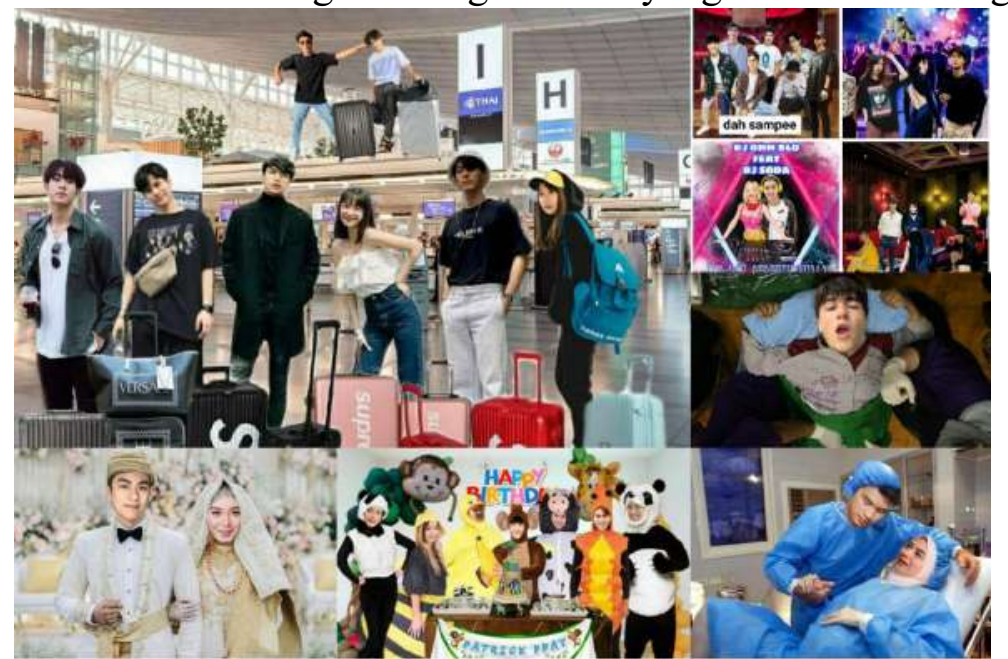

Sumber: Dokumentasi Peneliti dan Informan

Beragam kegiatan dan aktivitas dalam dunia RP diadaptasi dari kegiatan dan aktivitas yang datangnya dari dunia nyata, yang kemudian oleh manusia diciptakan lagi dalam ruang virtual atau cyberspace. Yanti Dwi Astuti (2015) dalam jurnalnya mengatakan bahwa dalam fenomena cyberspace ada sesuatu yang ekstra dalam dunia maya, bukan hanya bisa membangun peta pengalaman di dunia nyata. Kehidupan dunia RP bisa menjadi sangat real di benak setiap pemainnya tergantung bagaimana ia melakukan dan menerimanya. 4 tahap proses term simulacra yang terjadi dalam dunia RP ini:

1) Tanda (sign) merupakan presentasi dari realitas. Tanda yang dimaksud adalah aktivitas /kegiatan dunia RP yang menjadibentuk presentasi dari realitas dunia nyata.

2) Kemudian tanda mendistorsi realitas. Tanda tersebut akan mulai mendistorsi atau mengubah atau memutarbalikkan realitas dunia nyata manusia, khususnya para pemainnya. 
3) Realitas menjadi semakin kabur. Akhirnya, beragam aktivitas yang dilakukan dalam RP tersebut, membuat pemainnya terasa ada dalam dunia tersebut bahkan merasa dirinya adalah karakter yang dimainkannya.

4) Tanda tidak lagi menjadi realitas melainkan imaji telah menggantikannya. Imaji yang dimaksud disini adalah fakta-fakta atau kejadian-kejadian dalam dunia RP.

Manusia kini mampu menciptakan dan membuat dunia menjadi hal yang mungkin saat ini. Dunianya sendiri, dunia yang ideal baginya, dan dunia yang diinginkannya. Manusia saat ini bisa hidup dalam komputer, dalam ponsel genggam, "the world is flat" (Thomas L. Friedman, 2007). Bukan hanya pada dunia yang selama ini kita ketahui, atau dunia nyata, tapi manusia saat ini juga bisa hidup di dunia lain, dunia baru, dunia maya.

\section{Simpulan}

RP atau roleplay adalah sebuah permainan peran menjadi orang lain yang biasanya dilakukan oleh kelompok-kelompok penggemar dalam media sosial. Dunia RP adalah dunia khayal atau dunia imaji atau dunia ilusi yang diciptakan manusia yang diadaptasi dari dunia nyata namun diciptakan bebas sesuai kehendak manusia itu sendiri. Kelompok-kelompok penggemar pemain RP di media sosial ini kemudian akan menjadi komunitas virtual atau network society. Mereka berada dalam sebuah ruang virtual atau biasa disebut juga dengan cyberspace. Komunitas virtual RP dalam cyberspace ini kemudian akan memungkinkan terciptanya sesuatu yang disebut juga dengan dunia baru atau simulasi di dalam dunia maya.

Hal-hal aktivitas, atau kegiatan, dan kehidupan dalam RP ini tidak terlalu jauh berbeda dengan kehidupan dalam dunia nyata. Pencipta dari dunia ini adalah manusia yang hidup di dunia nyata, maka dunia baru yang tercipta dalam RP ini juga tidak akan jauh berbeda dengan dunia nyata. Beragam aktivitas tersebut contohnya seperti pernikahan dan perceraian, kelahiran, ulang tahun, khitanan, kehidupan malam atau clubbing, liburan, sekolah, dan lain sebagainya.

\section{Ucapan Terima Kasih}

Peneliti ucapkan terima kasih atas bantuan dan dukungan dari berbagai pihak dalam penelitian ini, antara lain narasumber, pembimbing, dan juga Fakultas Ilmu Komunikasi Universitas Tarumanagara.

\section{Daftar Pustaka}

Alyusi, Shiefti Dyah. (2016). Media sosial: interaksi, identitas dan modal sosial. Edisi pertama. Jakarta: Kencana.

Astuti, Yanti Dwi. (2015). Dari simulasi realitas sosial hingga hiper-realitas visual: tinjauan komunikasi virtual melalui sosial media di cyberspace. Jurnal Komunikasi PROFETIK. 08(02). 15-26.

Bostrom, Nick. (2003). Are we living in a computer simulation?. The Philosophical Quarterly. 53(211). 243-255.

Ghaissani, Nisya. (2017). Konstruksi identitas gender pada komunitas virtual roleplay (analisis etnografi virtual fenomena gender swap pada jejaring 
sosial twitter). Skripsi Program Studi Ilmu Komunikasi Fakultas Ilmu Sosial Dan Ilmu Politik Universitas Brawijaya Malang.

KBBI Daring. (5 September 2020). Diakses dari https://kbbi.kemdikbud.go.id/entri/interaksi

Moleong, Lexy J. (2017). Metodologi penelitian kualitatif. Edisi revisi. Bandung: PT. Remaja Rosdakarya.

Nasrullah, Rulli. (2017). Media sosial: perspektif komunikasi, budaya, dan sosioteknologi. Bandung: Simbiosa Rekatama Media.

Rizkinaswara, Leski. (5 September 2020). Penggunaan internet di Indonesia. KOMINFO RI Direktorat Jendral Aplikasi Informatika. Diakses dari https://aptika.kominfo.go.id/2019/08/penggunaan-internet-di-indonesia 